EDUKACJA MIĘDZYKULTUROWA

2015, nr 4

ISSN 2299-4106

VOLODYMYR LUGOVYY

Olena Slyusarenko

\title{
Missions and mottos of world-class institutions of higher education
}

Streszczenie: W rankingu szanghajskim najbardziej renomowanych 30 szkół wyższych zbadano 20 misji i 30 haseł oraz ujawniono ich różnorodność. Na podstawie analizy treści wyróżnione zostały grupy słów kluczowych, które najbardziej dokładnie charakteryzują misje ( 15 słów) oraz hasła (8 słów). Liczba i część tych słów $\mathrm{w}$ misji pozytywnie korelują z miejscem w rankingu. W drugim przypadku (części) korelacja utrzymuje się nawet dla 4 słów o najwyższej częstotliwości („edukacja”, „badania”, „wiedza”, „tworzyć”), potwierdzając pierwszeństwo jakościowego składu misji. Wprowadzone zostało pojęcie "misji skondensowanej (wzbogaconej)”. Wyróżnione zostały trzy typy sformułowań pojęcia „misja”. Scharakteryzowane zostały również hasła. Tylko dwa słowa kluczowe „wiedza” i „uczoność/nauka” są wspólne dla misji oraz haseł, co potwierdza niezbędność ich rozróżniania.

Słowa kluczowe: misja, najbardziej renomowane uczelnie wyższe, ranking shanghajski, misja skondensowana (wzbogacona), typy sformułowań misji

The previous publications, in particular of this article's authors, showed that the first 30 top higher education institutions in "Shanghai" ranking (Academic Ranking of World Universities) played a key role in the development of mankind $^{1}$. They account for over $40 \%$ of formation acts (education, internship,

1 Ауговий В. І. Використання міжнародних рейтингів вищих навчацьних закладів Аля іАентифікації найвищого університетського потенціалу / В. І. Ауговий, О. М. САюсаренко, Ж. В. Таланова // Вища освіта України. - Аодаток 2 до № 3, том I (26). - 2011 р. - Тематичний випуск «Вища освіта України у контексті інтеграції Ао європейського освітнього простору». - 700 с. - С. 296-308; Ауговий B. Нобелівські мауреати і топ-закцади вищої освіти, країни та континенти 3 передовим університетським потенціалом / В. Ауговий, С. Калашнікова, О. САюсаренко, Ж. Таланова // Теоретичний та науково-методичний часопис «Вища освіта України». - 2013. - № 4. - с. 128. - С. 10-20; Ауговий В. І. Стратифікація 
employment) of 847 Nobel Prize winners ${ }^{2}$. The discussed institutions are exemplary cases of stability, forming within their list for 2003-2013 (this article is prepared using the data of "Shanghai" ranking for 2003-2013) three stable (from 1, 5, and 5 institutions), one quasi-stable (15 institutions), and only one an unstable group (4 places) ${ }^{3}$. The first of them - Harvard University, is progressing rapidly and during the existence of the ranking it has gone ahead (from being the second) the leader of the second group - Stanford University. Amounting to less than $0.15 \%$ of higher education institutions of the world, the first 30 of them are worthy presenting. They are situated in major developed regions (North America, Western Europe and East Asia) and in successful countries (in order of the university capacity rank - the United States, the United Kingdom, Switzerland, Japan and Canada) ${ }^{4}$. It is noteworthy that even within the small compact and little changing set of the top discussed institutions,

та стійкість «орбіт» топ-закладів вищої освіти у світі / В. Ауговий, О. САюсаренко, Ж. Таланова // Теоретичний та науково-методичний часопис «Вища освіта України». - 2014. - № 2. - с. 128. - С. 13-20; Ауговий В. І. Університетологія - новий напрям педагогічної науки / В. І. Ауговий, О. М. САюсаренко, Ж. В. Таманова // Вища освіта України: теоретичний та науково-методичний часопис / [за реА. В. І. Аугового, М. Ф. Степка]. - К.: Запоріжжя: КАасичний приватний університет, 2012. - № 1. - Аодаток 2. - Тематичний випуск: «Наука і вища освіта». -368 с. - C. 3-11; Academic Universities - 2013. http://www.shanghairanking. com/ARWU2013.html (10.07.2014); Academic Universities - 2014. http://www. shanghairanking.com/ARWU2014.html (25.08.2014).

2 Ауговий В. Нобелівські цауреати і топ-заклади вищої освіти, країни та континенти з передовим університетським потенціалом / В. Ауговий, С. КаАашнікова, О. САюсаренко, Ж. Таланова // Теоретичний та науково-методичний часопис «Вища освіта України». - 2013. - № 4. - с. 128. - С. 10-20.

3 Ауговий В. І. Стратифікація та стійкість «орбіт» топ-закмадів вищої освіти у світі / В. Ауговий, О. Слюсаренко, Ж. Таланова // Теоретичний та науково-методичний часопис «Вища освіта України». - 2014. - № 2. - с. 128. - С. 13-20.

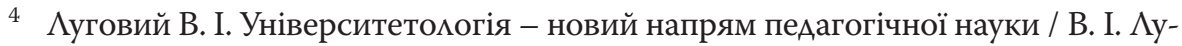
говий, О. М. САюсаренко, Ж. В. Тацанова // Вища освіта України: теоретичний та науково-методичний часопис / [за реА. В. І. Аугового, М. Ф. Степка]. - К.: Запоріжжя: КАасичний приватний університет, 2012. - № 1. - АоАаток 2. - Тематичний випуск: «Наука і вища освіта». - 368 с. - С. 3-11; Опубліковано новий рейтинг Webometrics (станом на 12.02.2014). http://www.euroosvita.net/index. $\mathrm{php} /$ ?category=1\&id=3099; Academic Universities -2013 . http://www.shanghairanking. com/ARWU2013.html (10.07.2014); Academic Universities - 2014. http://www. shanghairanking.com/ARWU2014.html (25.08.2014). 
there is a lot of diversification. For example, the $6^{\text {th }}$ in rate in 2013 ( $7^{\text {th }}$ in 2014) (the article takes into account the new data of "Shanghai" ranking of 2014), California Institute of Technology, has a concentrated profile, slightly more than 2000 students, while the comprehensive (classical) University of Toronto with the $28^{\text {th }}$ position $\left(24-25^{\text {th }}\right.$ in 2014$)$ - about 80000 students $^{5}$. In this regard the great scientific and practical interest is to identify common characteristics of the missions and mottos of those leading higher education institutions (hereinafter called - institutions, universities) in the world.

The purpose of the article is to identify, with the help of content and correlation analysis, the essential characteristics of the missions and mottos of top institutions holding the first 30 positions in the "Shanghai" ranking and to identify key words that show the essence of these missions and mottos.

The institutions themselves select and formulate missions and mottos for the purpose of self-identity, self-expression and self-determination of their activity. The mission is understood as the destination, generic appeal of organizations ${ }^{6}$, whereas motto as a brief statement of the main guiding ideas, the program of actions ${ }^{7}$.

In this paper, the missions and mottos are taken directly from the websites of institutions and e-mail addresses listed in the "Shanghai" ranking in $2013^{8}$. There were 20 accessible missions (67\%) and all 30 mottos of top rank institutions. In the case of Harvard University, due to lack of a unified university mission resulting from significant and considerable independence of university colleges and other units ${ }^{9}$, content analysis was carried out of the mission

5 Ауговий В. І. Стратифікація та стійкість «орбіт» топ-заклаАів вищої освіти у світі / В. Ауговий, О. САюсаренко, Ж. Таланова // Теоретичний та науково-методичний часопис «Вища освіта України». - 2014. - № 2. - с. 128. - С. 13-20; Academic Universities - 2013. http://www.shanghairanking.com/ARWU2013.html (10.07.2014); Academic Universities - 2014. http://www.shanghairanking.com/ ARWU2014.html (25.08.2014).

6 Словник іншомовних слів [за реА. О. С. Мельничука]. - К.: Гол. реА. Укр. раА. енц., 1977. - 776 с. - С. 441.

7 Словник іншомовних слів [за реА. О. С. Мельничука]. - К.: Гол. реА. Укр. раА. енц., 776 - .1977 с. - С. 191.

8 Academic Universities - 2013. http://www.shanghairanking.com/ARWU2013. html (10.07.2014).

9 Harvard University Statement of Values 8/02. http://www.harvard.edu/president/speeches/summers_2002/values.php (15.07.2014). 
of four leading Harvard colleges. These are the School of Education ${ }^{10}$, the School of Public Health ${ }^{11}$, the Business School ${ }^{12}$, the School of Engineering and Applied Sciences ${ }^{13}$. The University of Oxford as well is represented by one of its colleges ${ }^{14}$, and Imperial College London - by Graduate School ${ }^{15}$. Such individual replacement is acceptable taking into account the real assumption that the missions of the main structural units reflect the overall institutional context. For the credibility of the findings, it is important to notice the diversity of the above mentioned groups presented in 30 top institutions ${ }^{16}$ (according to ranking in $2013^{17}$ ), as could be seen in Table 1.

In order to do the investigation the frequency approach was used, according to which it is believed that the more frequently a word is used in a mission statement or motto, the more important (key) it is. The same (or cognate with) word repeatedly mentioned in one mission, was taken into account once. Thus, the frequency of occurrence is taken into account of certain words in different missions. For the purposes of this article the individual words that have a common (non-specific) helping meaning like "university", "institution", "college", or reflect the name or location of the institution "London's", "Oxford", etc. were not taken into account.

10 About the Harvard Graduate School of Education. http://www.gse.harvard.edu/ about/index.html (15.07.2014).

11 Mission E Objectives | About HSPH | Harvard School of Public Health. http:// www.hsph.harvard.edu/about/ (15.07.2014).

12 Mission - About Us - Harvard Business School. http://www.hbs.edu/about/ Pages/mission.aspx (15.07.2014).

13 Mission| Harvard School of Engineering and Applied Sciences. http://www.seas. harvard.edu/about-seas/mission (15.07.2014).

14 LMH, Oxford - Our mission and values. http://www.lmh.ox.ac.uk/AboutLMH/Vision-strategy/Our-mission-and-values.aspx (15.07.2014).

15 Mission Statement. http://www3.imperial.ac.uk/graduateschool/missionstatement (16.07.2014).

16 Ауговий В. І. Стратифікація та стійкість «орбіт» топ-закладів вищої освіти у світі / В. Ауговий, О. САюсаренко, Ж. Таланова // Теоретичний та науково-методичний часопис «Вища освіта України». - 2014. - № 2. - с. 128. - С. 13-20.

17 Academic Universities - 2013. http://www.shanghairanking.com/ARWU2013. html (10.07.2014). 
Table 1. "Mission" representation in stable, quasi-stable and unstable groups of top institutions in the $1^{\text {st }}-30^{\text {th }}$ places of "Shanghai" ranking in 2013

\begin{tabular}{|c|c|c|c|c|c|}
\hline \multirow[b]{2}{*}{ № } & \multirow[b]{2}{*}{$\begin{array}{c}\text { Groups } \\
\text { (ranking places) }\end{array}$} & \multirow{2}{*}{$\begin{array}{l}\text { Institu- } \\
\text { tions } \\
\text { in group }\end{array}$} & \multicolumn{2}{|l|}{ Institutions with missions under research } & \multirow[b]{2}{*}{ Countries } \\
\hline & & & Names & $\begin{array}{l}\text { Quantity } \\
\text { (share) }\end{array}$ & \\
\hline 1. & $\begin{array}{l}1^{\text {st }} \text { stable } \\
\left(1^{\text {st }} \text { rank }\right)\end{array}$ & 1 & Harvard University & $1(100 \%)$ & USA \\
\hline 2. & $\begin{array}{l}2^{\text {nd }} \text { stable } \\
\left(2^{\text {nd }}-6^{\text {th }} \text { rank }\right)\end{array}$ & 5 & $\begin{array}{l}\text { Massachusetts Institute of Technology, } \\
\text { University of Cambridge, } \\
\text { California Institute of Technology }\end{array}$ & $3(60 \%)$ & $\begin{array}{l}\text { USA, } \\
\text { UK }\end{array}$ \\
\hline 3. & $\begin{array}{l}3^{\text {rd }} \text { stable } \\
\left(7-11^{\text {th }} \text { rank }\right)\end{array}$ & 5 & $\begin{array}{l}\text { Columbia University, } \\
\text { University of Oxford }\end{array}$ & $2(40 \%)$ & $\begin{array}{l}\text { USA, } \\
\text { UK }\end{array}$ \\
\hline 4. & $\begin{array}{l}4^{\text {th }} \text { quasi-stable } \\
(12-24,26, \\
\left.28^{\text {th }} \text { rank }\right)\end{array}$ & 15 & $\begin{array}{l}\text { University of California, Los Angeles, } \\
\text { Cornell University, } \\
\text { University of California, San Diego, } \\
\text { University of Washington, } \\
\text { University of Johns Hopkins, } \\
\text { University of California, San Francisco, } \\
\text { University of Wisconsin-Madison, } \\
\text { Swiss Federal Institute of Technology Zurich, } \\
\text { University College London, } \\
\text { Imperial College London, } \\
\text { Kyoto University, } \\
\text { University of Toronto }\end{array}$ & $12(80 \%)$ & $\begin{array}{l}\text { USA, } \\
\text { UK, } \\
\text { Switzerland, } \\
\text { Japan, } \\
\text { Canada }\end{array}$ \\
\hline 5. & $\begin{array}{l}5^{\text {th }} \text { unstable } \\
(25,27,29 \\
\left.30^{\text {th }} \text { rank }\right)\end{array}$ & 4 & $\begin{array}{l}\text { University of Illinois at Urbana-Champaign, } \\
\text { New York University }\end{array}$ & $2(50 \%)$ & USA \\
\hline & Total & 30 & & $20(67 \%)$ & \\
\hline
\end{tabular}

Note: According to the "Shanghai" ranking of August 15, $2014^{18}$ there are the following findings: first, the unchanging list of the first 30 top institutions in recent years; second, the predicted fusion of the $2^{\text {nd }}$ and $3^{\text {rd }}$ group into one stable group of $10 \mathrm{in}$ stitutions in the $2-11^{\text {th }}$ places; third, the compact arrangement of the $4^{\text {th }}$ (now $3^{\text {rd }}$ ) quasi-stable group of $12-26$ ranks and $5^{\text {th }}$ (now $4^{\text {th }}$ ) unstable group $-27-30$ ranks.

Missions of different institutions vary a lot in the number of significant words from extremely compact at University College London, containing essentially one specific word ${ }^{19}$, to the very lengthy at Imperial College London (or rather in its Graduate School) of 38 words $^{20}$. It is noteworthy that both institutions are in one city in one country and in "Shanghai" ranking 2013 hold

18 Academic Universities - 2014. http://www.shanghairanking.com/ARWU2014. html (25.08.2014).

19 Mission, vision, values and guiding principles. http://www.ucl.ac.uk/white-paper/mission (16.07.2014).

20 Mission Statement. http://www3.imperial.ac.uk/graduateschool/missionstatement (16.07.2014). 
similar, respectively, $21-22^{\text {nd }}$ and $24^{\text {th }}$ rank (in $2014-20^{\text {th }}$ and $22-23^{\text {rd }}$ rank) ${ }^{21}$. This once again confirms the wide variety of extra-class institutions, even within a small sample of them. In general, the average "length" of a mission statement is 18 one-time words. The mission of the world leader Harvard University contains 23 words that are not repeated.

Decomposition into words of the missions of 20 institutions in total give 357 words, 172 of which are different, i.e. an average reproducibility of a word is a little more than twice. In fact, the repetition frequency of individual words in the missions of different institutions varies from 1 to 15 times, indicating a 15-fold difference significance of certain words, as shown in Table 2.

Table 2. Distribution of 172 mission words of 20 top institutions according to the frequency of use in different missions

\begin{tabular}{|c|c|c|c|c|}
\hline № & $\begin{array}{c}\text { Word } \\
\text { fre- } \\
\text { quency }\end{array}$ & $\begin{array}{c}\text { Word } \\
\text { number }\end{array}$ & Words & $\begin{array}{l}\text { Number of institutions } \\
\text { with the missions with- } \\
\text { out the relevant words" }\end{array}$ \\
\hline 1. & 15 & 1 & education & $5^{\mathrm{a}}$ \\
\hline 2. & 14 & - & - & - \\
\hline 3. & 13 & 1 & research & $3^{\mathrm{b}}$ \\
\hline 4. & 12 & - & - & - \\
\hline 5. & 11 & - & - & - \\
\hline 6. & 10 & 2 & knowledge, create & $2^{\mathrm{c}}$ \\
\hline 7. & 9 & 1 & students & $2^{\mathrm{c}}$ \\
\hline 8. & 7 & 2 & advance, serve & $2^{c}$ \\
\hline 9. & 6 & 4 & society, international, global, world & $1^{\mathrm{d}}$ \\
\hline 10. & 5 & 4 & public, teaching, discovery, learning & $1^{\mathrm{d}}$ \\
\hline 11. & 4 & 9 & $\begin{array}{l}\text { development, academic, faculty, professional, gradu- } \\
\text { ate, environment, excellence, scholarship, community }\end{array}$ & 0 \\
\hline 12. & 3 & 14 & $\begin{array}{l}\text { dissemination, programs, culture, promote, engaging, } \\
\text { inquiry, innovation, diverse, fields, undergraduate, } \\
\text { outstanding, benefit, sciences, collaborative }\end{array}$ & 0 \\
\hline 13. & 2 & 30 & $30(17.4 \%)$ other words & 0 \\
\hline \multirow[t]{2}{*}{14.} & 1 & 104 & $104(60.5 \%)$ other words & 0 \\
\hline & Total & 172 & $172(100 \%)$ words & 0 \\
\hline
\end{tabular}

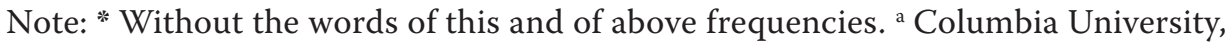
Cornell University, University College London, Kyoto University, University of Toronto; ${ }^{\mathrm{b}}$ Cornell University, University College London, Kyoto University; ${ }^{\mathrm{c}}$ University College London, Kyoto University; ${ }^{\mathrm{d}}$ Kyoto University.

21 Academic Universities - 2013. http://www.shanghairanking.com/ARWU2013. html (10.07.2014); Academic Universities - 2014. http://www.shanghairanking.com/ ARWU2014.html (25.08.2014). 
It is seen in Table 2 that in different missions only 15 words are found 5 times or more. They can be called the key (high-frequency), they are comparable in size with the average number of words in the mission (18 words), they constitute $8.7 \%$ of the different words and account for $32 \%$ of the total number of words. However, these words in a certain amount of missions are contained in all the considered institutions, except at Kyoto University. In each mission an average of about 6 key words - 38\% of the total, and an average of 39\% of the total number of words in the mission are used. The largest number (10) is used in the missions of Harvard ${ }^{22}$ and Columbia ${ }^{23}$ Universities. Key words differ significantly, their canonical (orthogonal) character is emphasized, and this enables full and complete display of different aspects of the mission of the modern institution leader. Obviously, the content of these words is clear and requires no further comment.

To confirm that these 15 key (highly-frequently used) are of determining power, the relationship was calculated between the ranking position of the institution in 2013 and the measure of the use of key words in the mission. For this purpose, Spearman rank correlation coefficient $\left(\mathrm{K}_{\mathrm{c}}\right)$ was used. Table 3 shows the calculated $\left(\mathrm{K}_{\mathrm{c}}\right)$ and critical $\left(\mathrm{K}_{\mathrm{cr}}\right)$ values of the coefficients for the two cases: between the rating position and a) the simple number of different key words in the mission, and b) the share of different keywords in the mission of a top institution.

Table 3. Spearman rank correlation coefficient for relationships between the ratings and the use of key words in the mission of the top institution

\begin{tabular}{|c|l|c|c|}
\hline \multirow{2}{*}{$№$} & \multicolumn{2}{|c|}{ Correlation coefficient } & \multicolumn{2}{c|}{ Measure of the use of keywords } \\
\cline { 3 - 4 } & & a) quantity & b) share of the mission \\
\hline 1. & Calculated value & $\mathrm{K}_{\mathrm{c}}=0.49$ & $\mathrm{~K}_{\mathrm{c}}=0.51$ \\
\hline 2. & Critical value & $\mathrm{K}_{\mathrm{cr}}=0.44$ & $\mathrm{~K}_{\mathrm{cr}}=0.38$ \\
\hline
\end{tabular}

22 About the Harvard Graduate School of Education. http://www.gse.harvard. edu/about/index.html (15.07.2014); Mission - About Us - Harvard Business School. http://www.hbs.edu/about/Pages/mission.aspx (15.07.2014); Mission | Harvard School of Engineering and Applied Sciences. http://www.seas.harvard.edu/about-seas/mission (15.07.2014); Mission \& Objectives | About HSPH | Harvard School of Public Health. http://www.hsph.harvard.edu/about/ (15.07.2014).

${ }^{23}$ Mission Statement | Columbia University in the City of New York. http://www. columbia.edu/content/mission-statement.html (15.07.2014). 
Table 3 shows valid (with standard 0.95 probability) correlation between rating and presence of the key words in the mission of the institution.

Moreover, the question can be raised concerning the range of different words due to their frequency (with quantities and shares of the mission), which show valid correlation with the top institution rank. The calculations are provided in Table 4.

Table 4. Spearman rank correlation coefficient for dependencies between rating and (A) quantity of different words due to frequency, and (B) share of these words in the mission of a top institution

\begin{tabular}{|c|c|c|c|c|c|c|c|c|c|c|c|c|}
\hline \multirow{2}{*}{ № } & \multirow{2}{*}{$\begin{array}{c}\text { Correlation } \\
\text { coefficient }\end{array}$} & $\begin{array}{c}1 \\
(15)\end{array}$ & $\begin{array}{c}2 \\
(13+)\end{array}$ & $\begin{array}{c}4 \\
(10+)\end{array}$ & $\begin{array}{c}5 \\
(9+)\end{array}$ & $\begin{array}{c}7 \\
(7+)\end{array}$ & $\begin{array}{c}11 \\
(6+)\end{array}$ & $\begin{array}{c}15 \\
(5+)\end{array}$ & $\begin{array}{c}24 \\
(4+)\end{array}$ & $\begin{array}{c}38 \\
(3+)\end{array}$ & $\begin{array}{c}68 \\
(2+)\end{array}$ & $\begin{array}{c}172 \\
(1+)\end{array}$ \\
\hline \multicolumn{10}{|c|}{ A. Quantity of different words due to frequency } \\
\hline 1. & $\mathrm{~K}_{\mathrm{c}}$ & 0.42 & 0.31 & 0.39 & 0.43 & 0.49 & 0.50 & 0.49 & 0.37 & 0.22 & 0.17 & 0.10 \\
\hline 2. & $\mathrm{~K}_{\mathrm{cr}}$ & $\mathrm{K}_{\mathrm{cr}}>0.53>\mathrm{K}_{\mathrm{c}}$, not valid & 0.44 & \multicolumn{7}{c|}{$\mathrm{K}_{\mathrm{cr}}=0.38>\mathrm{K}_{\mathrm{c}}$} \\
\hline \multicolumn{10}{|c|}{ B. Share of different words in the mission } \\
\hline 3. & $\mathrm{~K}_{\mathrm{c}}$ & 0.37 & 0.23 & 0.48 & 0.56 & 0.66 & 0.52 & 0.51 & 0.28 & 0.21 & 0.12 & \multirow{2}{*}{$*$} \\
\hline 4. & $\mathrm{~K}_{\mathrm{cr}}$ & $\mathrm{K}_{\mathrm{cr}}=0.38>\mathrm{K}_{\mathrm{c}}$ & \multicolumn{8}{c|}{$\mathrm{K}_{\mathrm{cr}}=0.38<\mathrm{K}_{\mathrm{c}}$, valid } & $\mathrm{K}_{\mathrm{cr}}=0.38>\mathrm{K}_{\mathrm{c}}$ & \\
\hline
\end{tabular}

Note: * not applicable because of the absence of variation

The following conclusions can be drawn from Table 4 .

As for the number of different words in the mission, it is only in the case of the first 15 high-frequency (key, canonical) words that there is a correct correlation. Less than 15 (1, 2, 4, 5, 7 and 11) and more than $15(24,38,68$ and 172) means that the number of different words do not provide the accuracy of the relationship. The reasons are likely to be the following. In the first case, it is an increase (up to large quantities) of the critical value of the correlation coefficient under reducing the (statistically small sample) number of independent words - their numerical deficiency (with all weight of each word). In the second case, it is the reduced integral weighting of different words (an effect of addition some not essential words to their set).

The situation with shares of various words in the mission is somewhat different. Since in this case the choice of rank pairs is constant - 20, the critical value of the correlation coefficient for all cases is stable and equals 0.8 . As can be seen from Table 4, the range of validity is much larger: it begins with the 4 most frequent words ("education", "research", "knowledge", "create") and ends with 15 key words mentioned. Thus, the qualitative indicator of the 
presence of different essential words (their share) in the mission appeared to be a priority for the top institution rating as compared to the quantitative one. There is an essential explanation of this: even with a large number of key words, in lengthy missions they can veil the multitude of not essential words. That is, the effectiveness of defining, orienting and focusing functions of the mission in the second case decreases (increasing its total disorienting and deconcentrating role). A mission with a great deal of different high-frequency words can be called concentrated (enriched).

There is a reason to believe that the conclusions based on the data in Table 3 and 4 are valid for the ranking of 2014, in which compared to 2013 there were no significant changes ${ }^{24}$ (Spearman rank correlation coefficient for the first 30 places of the top institutions in 2013 and 2014 is 0.98 , which indicates a very strong similarity of distributions).

Three types of mission formulations of top institutions have been distinguished.

In the first type, the generic specificity of institution is identified firstly, and after that its higher purpose of serving the mankind. For example, this type of representation is used in the mission of Johns Hopkins University ("The mission of The Johns Hopkins University is to educate its students and cultivate their capacity for life-long learning, to foster independent and original research, and to bring the benefits of discovery to the world." ${ }^{25}$ ).

In the second type, on the contrary, a higher purpose in relation to human development is determined firstly, and only then its subordinate institution. An example is the mission of the University of Cambridge ("The mission of the University of Cambridge is to contribute to society through the pursuit of education, learning, and research at the highest international levels of excellence" ${ }^{26}$. Or, for example, the mission of the University of Illinois: "Mission. The University of Illinois will transform lives and serve society by educating,

24 Academic Universities - 2013. http://www.shanghairanking.com/ARWU2013. html (10.07.2014); Academic Universities - 2014. http://www.shanghairanking.com/ ARWU2014.html (25.08.2014).

25 The Johns Hopkins University - A Brief History of JHU. http://webapps.jhu.edu/ jhuniverse/information_about_hopkins/about_jhu/a_brief_history_of_jhu/index.cfm (11.01.2014).

26 The University's mission and core values | University of Cambridge. http://www. cam.ac.uk/about-the-university/how-the-university-and-colleges-work/the-universitys-mission-and-core-values. (15.07.2014). 
creating knowledge and putting knowledge to work on a large scale and with excellence" 27 .

In the third type, the focus is exclusively on the higher (and apparently mediated) appeal of institution, often losing the original generic certainty of organization. For example, in the very main text of the mission of the Kyoto University one can guess to which proper organization it belongs ("Mission Statement. ... states its mission to sustain and develop its historical commitment to academic freedom and to pursue harmonious coexistence with human and ecological community on this planet" ${ }^{28}$ ). Specific institutional identification through the mission is difficult in the absence of the latter key words. Only the words at smaller (4-fold) repeatability concretize the mission of this institution - "develop", "academic", and "community". Likewise, "globally" reduced - to one meaningful word - the mission of University College London, even though it contains the key word "global", to clarify the institutional features two more words are included "London's" and "university" ("The mission. UCL is London's global university." ${ }^{29}$ ), which, as noted above, does not carry a specific "mission" load.

However, in any of the three types of mission statements, a high universal appeal of the top world-class institutions has been reflected.

As regards mottos, they are characterized in the following way.

Mottos are more brief than the missions. Dictionary decomposition of mottos revealed only 52 essential words (on average fewer than two words in one motto), including 27 different (average repetition frequency of about two times). The amount of these words is accordingly almost 7 times and more than 6 times smaller as compared to the missions. The range of variation of the frequency of different words is from 1 to 9 times (see Table 5), i.e. in 1.7 times smaller than for missions.

The shortest motto, expressed in just one word, is of Harvard University "Truth" 30 . The part of mottos are composed of one main and several auxiliary

27 Mission E Vision - University of Illinois. http://www.uillinois.edu/about/mission (16.07.2014).

28 Mission Statement - Kyoto University. http://www.kyoto-u.ac.jp/en/profile/ ideals/basic/index.htm/ (16.07.2014).

29 Mission, vision, values and guiding principles. http://www.ucl.ac.uk/white-paper/mission (16.07.2014).

30 Harvard at a Glance | Harvard University. http://www.harvard.edu/harvard-glance (26.08.2014). 
words. Short mottos can be exemplified by "Let there be light" at the Universities of California - Berkeley, Los Angeles, San Diego, San Francisco, and the University of Washington ${ }^{31}$. A significant part of the mottos include two essential words: "Mind and hands" at the Massachusetts Institute of Technology ${ }^{32}$, "Light and truth" at Yale University ${ }^{33}$, "God - our light" in the University of Wisconsin-Madison ${ }^{34}$, "Learning and Labor" at the University of Illinois Urbana-Champaign ${ }^{35}$. Some mottos consist of three basic words such as "Arts, Knowledge, and Truth" at the University of Michigan, Ann Arbor ${ }^{36}$. There are more complex mottos as well.

An analysis of the dictionary mottos composition is presented in Table 5.

Table 5 shows that 8 different key words with frequency of use from 9 to 2 times in the mottos should be recognize. Overall, they accounted for $30 \%$ different and $63 \%$ of all words. They are used in 25 (83\%) of the 30 top institutions.

Table 5. Distribution of 52 essential words of mottos by frequency of use in different 30 top institutions

\begin{tabular}{|c|c|c|c|l|c|}
\hline № & $\begin{array}{c}\text { Fre- } \\
\text { quency } \\
\text { of use }\end{array}$ & $\begin{array}{c}\text { Num- } \\
\text { ber of } \\
\text { words }\end{array}$ & Total & Words & $\begin{array}{c}\text { Number of institutions with mot- } \\
\text { tos without appropriate words* }\end{array}$ \\
\hline 1. & 9 & 1 & 9 & light & 21 \\
\hline 2. & 8 & - & - & - & - \\
\hline 3. & 7 & 1 & 7 & truth & 15 \\
\hline 4. & 6 & - & - & - & - \\
\hline 5. & 5 & - & - & - & - \\
\hline
\end{tabular}

31 Extraordinary Past, Extraordinary Promise: UCSD Welcomes a Dynamx ic New Chancellor. http://ucsdnews.ucsd.edu/archive/thisweek/2005/mar/03_07_ inauguration.asp (27.08.2014); Facts at a glance - UC Berkeley. http://berkeley.edu/ about/fact.shtml (26.08.2014); UCLA Commencement. https://www.commencement. ucla.edu/history (26.08.2014); University of California, San Francisco - Wikipedia, the free encyclopedia. http://en.wikipedia.org/wiki/University_of_California,_San_ Francisco (27.8.2014); Washington Commons - About - UW Alumni Association. http://www.washington.edu/alumni/about/commons.html (26.08.2014).

32 MIT Facts 2014: MIT at a Glance. http://web.mit.edu/facts/faqs.html (26.8.2014).

33 About | Yale Kendo. http://kendo.commons.yale.edu/about/(26.8.2014).

34 Wisconsin alumni association. https://www.uwalumni.com/askabe/numen-lut men/ (26.08.2014).

35 Alma Mater | Campus Tours | Illinois. http://illinois.edu/tours/CampusTourc67c. html (26.08.2014).

36 Overview | Bicentennial. http://bicentennial.umich.edu/about/overview/ (26.08.2014). 
Table 5 continued

\begin{tabular}{|r|r|r|r|l|c|}
\hline 6. & 4 & 2 & 8 & freedom, knowledge, & 10 \\
\hline 7. & 3 & 1 & 3 & god, lord & 9 \\
\hline 8. & 2 & 3 & 6 & learning, arts, flourish, persevere & $5^{\text {a }}$ \\
\hline 9. & 1 & 19 & 19 & $19(70 \%)$ other words & 0 \\
\hline & Total & 27 & 52 & $27(100 \%)$ words & 0 \\
\hline
\end{tabular}

Note: * Without a word of this and of above frequencies. ${ }^{a}$ Massachusetts Institute of Technology, University of Pennsylvania, Swiss Federal Institute of Technology Zurich, University College London, University of Toronto.

The comparison of key words of missions and mottos shows that only two of them ("knowledge" and "learning") are common. The latter have 13\% and $25 \%$ of the relevant key words, thus confirming the substantial difference between missions and mottos. This is understandable, because the mottos often reflect an old tradition and are often of allegorical or symbolic nature.

The issues discussed above make it possible to draw the following conclusions.

First. The higher education institutions which occupy the first 30 places in the "Shanghai" ranking are characterized by a variety of missions and mottos. This diversity is expressed verbally, both quantitatively and qualitatively. However, a group of key words that are used frequently can be selected they are the most essential.

Second. Averagely over 20 (67\%) of the top institution missions contains 18 words with a range of variation from one to 38 words in each case. The total number of words is 357 and the number of different words -172 . The range of repetition rate is from 15 to 1 . There are 15 key words with frequency of use from 15 to 5 times in the missions. They are in all but one of the top institutions studied. The quantity of words and their share in the mission show a significant correlation with the ranking positions. Moreover, in the case of shares such correlation exists even for the 4 most high-frequency words ("education", "research", "knowledge", "create"), indicating the priority of the qualitative composition of the mission over the quantitative. In other words, the key words' concentrated mission is more defining, orienting and mobilizing for the institution. To illustrate such a circumstance, it is advisable to introduce the concept of "concentrated (enriched) mission".

Third. There are three types of mission formulations, depending on the correlation (superiority) in it of the universal and institutional roles. However, in any case, the mission is reflected in high universal appeal of top world-class institution. 
Fourth. Mottos of 30 top institutions are significantly laconic - in average about two words for the institution, starting with one, but only 52 essential words are used, of which 27 are different. The frequency of repetition varies from 9 to 1 . In the case of mottos, 8 key words can be identified which are used in 25 (83\%) of the top institutions.

Fifth. The comparison of 15 and 8 key words missions and mottos shows that only two of these words - "knowledge" and "learning" - are common. On one hand, it confirms the need for a fundamental distinction of the terms "mission" and "motto"; and on the other hand, to some extent, it indicates that they belong to the basic characteristics of modern institutions of higher education.

In this article, the idea of the research of missions and mottos of 30 top institutions, the choice of research methods (frequency content analysis, correlation statistics) and the corresponding calculations should be attributed to O. Slyusarenko; the discussion, synthesis and formulation of the results - to both V. Lugovyy and O. Slyusarenko.

\section{Bibliography}

Ауговий В. І. Використання міжнародних рейтингів вищих навчальних закладів Аля іАентифікації найвищого університетського потенціаму/В. І. Ауговий, О. М. САюсаренко, Ж. В. Таланова // Вища освіта України. - Аодаток 2 до № 3, том I (26). - 2011 р. - Тематичний випуск «Вища освіта України у контексті інтеграції до європейського освітнього простору». - 700 с. - С. 296-308.

Ауговий В. Нобелівські мауреати і топ-заклади вищої освіти, країни та континенти з передовим університетським потенціалом / В. Ауговий, С. Камашнікова, О. Слюсаренко, Ж. Тацанова // Теоретичний та науково-методичний часопис «Вища освіта України». - 2013. - № 4. - с. 128. - C. 10-20.

Ауговий В. І. Стратифікація та стійкість «орбіт» топ-закмаАів вищої освіти у світі / В. Ауговий, О. САюсаренко, Ж. Таланова // Теоретичний та науково-методичний часопис «Вища освіта України». - 2014. - № 2. с. $128 .-$ C. 13-20.

Ауговий В. І. Університетологія - новий напрям пеАагогічної науки / В. І. Ауговий, О. М. САюсаренко, Ж. В. Таланова // Вища освіта 
України: теоретичний та науково-методичний часопис / [за реА. В. І. Аугового, М. Ф. Степка]. - К.: Запоріжжя: Кмасичний приватний університет, 2012. - № 1. - Аодаток 2. - Тематичний випуск: «Наука і вища освіта». - 368 с. - С. 3-11.

Опубліковано новий рейтинг Webometrics (станом на 12.02.2014). http:// www.euroosvita.net/index.php/?category $=1$ \&id $=3099$.

Словник іншомовних слів [за реА. О. С. Мельничука]. - К.: Гол. реА. Укр. раА. енц., 1977. - 776 с.

About the Harvard Graduate School of Education. http://www.gse.harvard. edu/about/index.html (15.07.2014).

About | Yale Kendo. http://kendo.commons.yale.edu/about/(26.8.2014).

Academic Universities - 2013. http://www.shanghairanking.com/ARWU2013. html (10.07.2014).

Academic Universities - 2014. http://www.shanghairanking.com/ARWU2014. html (25.08.2014).

Alma Mater | Campus Tours | Illinois. http://illinois.edu/tours/CampusTourc67c.html (26.08.2014).

Extraordinary Past, Extraordinary Promise: UCSD Welcomes a Dynamic New Chancellor. http://ucsdnews.ucsd.edu/archive/thisweek/2005/mar/03_07_ inauguration.asp (27.08.2014).

Facts at a glance - UC Berkeley. http://berkeley.edu/about/fact.shtml (26.08.2014). Harvard at a Glance | Harvard University. http://www.harvard.edu/harvard-glance (26.08.2014).

Harvard University Statement of Values 8/02. http://www.harvard.edu/president/speeches/summers_2002/values.php (15.07.2014).

LMH, Oxford - Our mission and values. http://www.lmh.ox.ac.uk/AboutLMH/Vision-strategy/Our-mission-and-values.aspx (15.07.2014).

Mission - About Us - Harvard Business School. http://www.hbs.edu/about/ Pages/mission.aspx (15.07.2014).

Mission | Harvard School of Engineering and Applied Sciences. http://www. seas.harvard.edu/about-seas/mission (15.07.2014).

Mission E Objectives | About HSPH | Harvard School of Public Health. http:// www.hsph.harvard.edu/about/ (15.07.2014).

Mission Statement. http://www3.imperial.ac.uk/graduateschool/missionstatement (16.07.2014).

Mission Statement | Columbia University in the City of New York. http:// www.columbia.edu/content/mission-statement.html (15.07.2014). 
Mission Statement - Kyoto University. http://www.kyoto-u.ac.jp/en/profile/ ideals/basic/index.htm/ (16.07.2014).

Mission \& Vision - University of Illinois. http://www.uillinois.edu/about/mission (16.07.2014).

Mission, vision, values and guiding principles. http://www.ucl.ac.uk/white-paper/mission (16.07.2014).

MIT Facts 2014: MIT at a Glance. http://web.mit.edu/facts/faqs.html (26.08.2014).

Overview | Bicentennial. http://bicentennial.umich.edu/about/overview/ (26.08.2014).

The Johns Hopkins University - A Brief History of JHU. http://webapps.jhu. edu/jhuniverse/information_about_hopkins/about_jhu/a_brief_history_ of_jhu/index.cfm (11.01.2014).

The University's mission and core values | University of Cambridge. http:// www.cam.ac.uk/about-the-university/how-the-university-and-colleges-work/the-universitys-mission-and-core-values (15.07.2014).

UCLA Commencement. https://www.commencement.ucla.edu/history (26.08.2014).

University of California, San Francisco - Wikipedia, the free encyclopedia. http://en.wikipedia.org/wiki/University_of_California,_San_Francisco (27.08.2014).

Washington Commons - About - UW Alumni Association. http://www.washington.edu/alumni/about/commons.html (26.08.2014).

Wisconsin alumni association. https://www.uwalumni.com/askabe/numen-lumen/ (26.08.2014).

\section{Missions and mottos of world-class institutions of higher education}

\section{Summary}

In this article, 20 missions and 30 mottos of the first 30 higher education institutions in the "Shanghai" ranking are studied and their diversity is revealed. Key words groups which characterize the missions (15 words) and mottos ( 8 words) in the most definite way have been identified on the basis of content analysis. The number and share of these words in the mission are positively correlated with the ranking positions of institutions. In the second case (share) the corre- 
lation is maintained even for 4 the most frequent words ("education", "research", "knowledge", "create"), indicating the priority of the qualitative composition of the mission. The concept of "concentrated (enriched) mission" is introduced. There are three types of mission formulations. Mottos are characterized as well. Only two key words "knowledge" and "learning" are common for missions and mottos, which confirms the principal need to distinguish between the two.

Key words: mission, motto, top higher education institutions, the Shanghai ranking, content and correlation analysis, concentrated (enriched) mission, types of mission formulations

Translated by Volodymyr Lugovyy, Olena Slyusarenko 